\title{
The Aesthetic Concept of Marketing as a Factor for the Development of Modern Consumer Culture
}

\author{
Elena A. Nozdrenko* \\ Siberian Federal University \\ 79 Svobodny, Krasnoyarsk, 660041, Russia
}

Received 12.12.2016, received in revised form 08.02.2018, accepted 12.02.2018

The development of consumer culture is one of the fundamental ways of interacting with society and managing its consciousness. This fact determines the penetration of marketing in all spheres of life, and the constant search for new ways to stimulate consumption actualizes the development of its aesthetic concept. In modern conditions, this phenomenon becomes especially urgent, since it is the main instrument of an effective market strategy, and one of the factors that contribute to the formation of consumer culture, and hence the culture of society as a whole.

Keywords: marketing, aesthetics, advertising, culture, consumer, aesthetic concept.

DOI: 10.17516/1997-1370-0223.

Research area: culturology.

\section{Topicality of the research}

As the result of rapid development of market relations, mass production and consumption of goods has become a key factor in the economic and social well-being of the modern world. The social state of modern society is consumer society, the consumption process has an impact not only on the economic, but also on the sociocultural sphere of society. In this regard, consumption has become one of the main patterns of behaviour that facilitates the organization and arrangement of a modern cultural space with an appropriate system of values and attitudes. The conditions for the development of society define an effective marketing strategy as one of the main tasks of social institutions. The possibility of active consumption becomes a symbol of self-realization of an individual, achievement of a necessary social status. Consequently, a powerful influence of informative and persuasive technologies (MCT, show business, film industry, PR technologies, advertising) on all spheres of society became the fundamental condition for the dynamics of the development of the culture of society. We believe that today the aesthetics of marketing as one of the main means involved in the development of culture of consumption, has an impact on the development trends of modern society.

(C) Siberian Federal University. All rights reserved

* Corresponding author E-mail address: elena.nozdrenko@mail.ru 


\section{State of knowledge \\ of the topic}

In modern domestic and foreign science, the problems of marketing aesthetics have not been practically studied, and it is becoming increasingly important and relevant.

Among domestic studies, the aesthetics of marketing is represented by the problems of its modern discourse in the works of M.V. Stepanova (Stepanova, 2014) and V.M. Brezhneva (Brezhneva, 2012); in the context of the culture of marketing in the manual by V.E. Novatorov (Novatorov, 2011) and from the point of view of revealing the role of aesthetics in the branding strategy in the article of T.N. Zhukova (Zhukova, 2013).

In the indexed foreign publications, various aspects of the aesthetic content of marketing are given: 1) from the position of strategic management, brand building and company image (Schmitt, Simonson, 2005); 2) from the point of view of integration of aesthetics into everyday consumption (Venkatesh, Meamber, 2008); 3) the introduction of the potential of aesthetics in the study of marketing as a scientific discipline (Petkus et al., 2011); 4) identification of differences between an aesthetic product and aesthetic consumption from the point of view of marketing views (Charters, 2006); 5) in the aspect of studying social dynamics at the level of aesthetics of everyday consumption (Hewer, Brownlie, 2010); 6) the definition of the role of consumer happiness in marketing relationships (Belanche et al., 2013); 7) conceptualization of culture in the process of marketing management (McCort, Malhotra, 2008); 8) acculturation of global consumer culture in the framework of national marketing (Carpenter et al., 2013); 9) modeling of consumer behaviour in the locus of marketing philosophy (Thrassou, Vrontis, 2009).

\section{Culture of consumption as a phenomenon}

Modern society demonstrates the need for a constant desire to consume. The emergence and satisfaction of new needs has become an integral part of society. And the phenomenon of globalization contributed to the fact that the trends in the spread of consumer values are not local, but ubiquitous. Currently almost all researchers of the sociocultural processes of reality are considering modern culture in the context of the development of consumer society.

The change in the status of the consumption phenomenon occurred, at least, for two reasons: 1) in modern reality, practically all things in a symbolic sense become obsolete earlier than in the material one. We acquire the product (service) not so much for its functional use, as for the awareness of the status and significance of the acquisition; 2) the process of consumption itself is infinite, that is, it loses its features of limit and exhaustibility.

Practice shows that one of the leading characteristics of modern man is his hypermateriality, since the very presence of various material objects seem to them as a fundamental component of life activity. With the help of materials, we have the opportunity to characterize our activities, express our thoughts and feelings, etc. Materialization makes it possible to correlate with various subjects of one's own reality. Consequently, all sorts of attributes of modern everyday life convey not so much a functional load as semantic and symbolic one.

It is known that consumption is an identifier of social characteristics of a person, their belonging to the desired social group. Many researchers believe that consumption is broadcast as the meaning of life, as people get an opportunity to assert themselves and gain a certain position in society. We believe that the genesis of the phenomenon of consumption has 
led to a kind of substitution of basic concepts, values and ideals in society. Consumption has a global impact on all spheres of society (not only economic). And the study of the phenomenon of consumption in the context of its socio-cultural impact seems to be an important element in the development of various concepts and theories relating to the successful and harmonious development of society.

Consumption is not at all simple satisfaction of biological needs, but shows the attitude of a person to things, ideas, other people, to the world as a whole (according to J. Baudrillard). Not achieving satisfaction, we make this process endless. Subjects are endowed with the value of prestige, referring to the social rank of their possessor, turn into distinctive social markers, become carriers of indexed social meanings, social and cultural hierarchy.

Therefore, the essence of consumption can be generally defined as a specific socio-cultural activity of a person possessing the characteristics of infinity, simulativeness and significance. In turn, the development of consumer society has contributed to the transformation of all spheres of life of society. Each era offers a person certain basic models and values that organize their whole life process. There is building of this or that model, the picture of the world. One can say that in the current reality, consumption has become one of such basic models that determine and organize the filling and space of modern culture.

Culture, as a human-created habitat and a form of reproducing ideals and values, comes from the past, basing on the present and the future. Nevertheless, if we talk about its specific ways of manifestation, elements and relationships, it reflects, above all, precisely the surrounding reality in which it functions. Accordingly, cultural forms depend on the stage of the development of society, its values and life orientations. It turns out that cultural development is associated with the path of society development, which in turn, is influenced by it as well.

Many researchers define culture as a programme for human life and society as a whole. Culture is the phenomenon that programs, regulates, conditions and influences not only how a single individual lives and functions, but also society as a whole. It cannot be overlooked that consumption factors influence the formation of a special type of cultural forms, namely, culture of consumption. Hyper-materiality, simulativeness, infinity and symbolism of consumption contribute to the fact that the cultural sphere adopts these features. Consumer values become an element of both culture and everyday life. Due to the fact that the category of consumption takes an increasing place in social processes, the concept of consumption culture begins to take on an increasingly important position and carries the semantic loads, orientations, ideals, values, standards and behaviour models that are formed in the course of consumer society development.

Therefore, culture of consumption is a complex and ambiguous phenomenon, an important component of modern culture in the global sense. This phenomenon has recently had an increasing impact on the formation of certain trends in society. In particular, the process of socialization and acculturation of an individual in society is always accompanied by the need for successful development of all elements of culture and culture of consumption, in particular. Today, culture of consumption becomes a specific practice that allows to perform vital activities and demonstrate corresponding reactions to external processes.

\section{Aesthetics of marketing}

In the conditions of dynamically developing consumer culture, there is a constant search for new patterns, values, styles, forms and trends. Under the all-consuming impact of 
communication and advertising, a certain aestheticization of reality takes place, which, in our opinion, requires a more detailed study of the role of marketing and its aesthetic aspect in society, since this phenomenon is one of the main factors in the formation of consumer culture and its forms. However, this problem is almost uncovered, and no unified understanding of the essence of marketing aesthetics (aesthetics from Greek as "perceived by the sensory organs") has not been found in Russian science.

Foreign researchers consider this aspect in different aspects.

1. The problems of aesthetic consumption, which are: internal value in comparison with instrumental, emotions, sensual pleasure, beauty, context and the formation of taste (Venkatesh, Meamber, 2008).

2. The theory of aesthetic experiences in the process of consumption. The issue of the influence of postmodernism on the aesthetics of marketing is examined through a number of philosophical dilemmas: disinterested attention, objective and subjective taste, the character of the aesthetic encounter and the relationship of evaluation with preference (Charters, 2006).

3. Dialectics of the theory of consumer culture and the phenomenon of branding (Hewer, Brownlie, 2010). Analyzing the relationship between the social dynamics of markets and the level of everyday consumption, P. Hewer and D. Brownlie believe that consumers can become active players in creating new opportunities for constructing identity in the aesthetic component of marketing.

4. The impact of culture on consumer behaviour in the management of marketing. From the perspective of cross-cultural psychology and anthropology, the process of influencing the culture of consumer behaviour that relates to the value system and the self-evaluation of target segments is considered (McCort, Malhotra, 2008).
5. Development of supranational segments of national marketing in the context of acculturation of global consumer culture. Cosmopolitanism and social interaction consistently reduce the level of racism in specific markets (Carpenter et al., 2013).

6. Management of perception in the process of modeling relations with a new consumer. It has been determined that consumer needs are most often manifested in desires that are intangible or ambiguous, emotional in nature, and vulnerable to marketing communications (Thrassou, Vrontis, 2009).

Currently, the boundaries of understanding the phenomenon of "marketing aesthetics" go far beyond the economic sphere only. If the essence of aesthetics is associated with associative perception, the success of marketing today is impossible without the competent promotion of aesthetic properties of the product (goods, services, ideas, etc.). Now the marketing function is performed by all objects and subjects of modern reality, the markets are interested in creation, promotion and successful sale of the product. The implementation of effective marketing activities is a fundamental indicator of success and stability of a company, person or idea. The object of consumption must have actual consumer qualities and not so much ensuring compliance with normative and legitimate requirements, but relevant to the reality of cultural forms and traditions. In this case, the aesthetic component of marketing becomes decisive in determining the ways of the consumer culture development.

Almost every aspect of social life can be a source of aesthetics, which absorbs and concentrates the uniqueness of any socio-historical specifics (according to A.F. Losev). Currently, the whole world in its aesthetic manifestation is the object of modern aesthetics, in accordance with all its phenomena and their universal significance. If earlier the categories of "beautiful" and "ugly" 
were fundamentally important, now it includes the aesthetic properties of reality, as well as the processes occurring in the course of aesthetic exploration of the world by man, their perception of everything that is happening, etc. Of course, the aesthetic system continues to be based on the category of "beautiful", because, first of all, any object should bring aesthetic pleasure to a person. Therefore, today we can talk about a broader and more extensive category of marketing, aesthetic one, in which the diversity of reality is manifested in its most general meaning for all mankind on the basis of its experience, historical development and practical mastery of the world.

All forms of aesthetic activities of society and its products define such concepts as aesthetic views, tastes, ideals, aesthetic perception, representation. All these factors contribute to the spiritual and cultural experience of society, remembering of certain aesthetic ideas, their evaluation and consolidation, the formation of a system of aesthetic preferences and orientations, the formation of aesthetic ideals as a concept of higher harmony and perfection in the reality of culture.

If the aesthetic concept determines the artistic practice of mankind, the value aspects of their material and spiritual activity, then in the sphere of marketing it is an aesthetic comprehension and manifestation of the concept of advancement based on the current spiritual and cultural paradigm of the target market segments.

The specificity of the aesthetic concept of marketing lies in the fact that it can be viewed in the context of several aspects at once:

- the impact of marketing aesthetics on the surrounding reality. Aesthetic categories are able to transform all spheres of life of society. Here we can talk about the formation of certain spiritual and cultural forms, values and orientations of target audiences;
- the artistic impact through the broadcast images. Thus, for example, advertising and PR are appealing with artistic forms and categories;

- the socio-communicative factor of the aesthetic content of marketing. Mass media are manipulative in the process of promoting the product on the market;

- meaningful transformation of the advertising message in the process of its decoding by the consumer. One of the most important factors in this process is internal filters (values, norms, ideals, etc.) and culture of consumption;

- harmonization of the process of product development, creation and registration. The aesthetic component of design (packaging, design, etc.) of the product is a matter of marketing aesthetics;

- the social practice of the consumer associated with the development of habits, traditions and norms, aesthetics of life and livelihoods is largely related to the aesthetic content of marketing.

Thus, modern marketing is not just a market activity, but a significant sociocultural practice that shapes the development tendencies of society. Aesthetics of marketing is a special approach to the creation and promotion of an object (product/ service/idea/personality/organization/social institution) based on the formation of spiritual and cultural orientations of society and their skillful application, which is aimed at achieving profitable and effective relationships of all participants of market relations, thus influencing the sociocultural processes of modern reality. Aesthetics of marketing allows us to understand how to meet the needs of consumers and producers, taking into account aesthetic views, tastes and ideals conditioned by the generally accepted aesthetic concept and culture of society.

Understanding the aesthetics of marketing and its specificity allows us to say that this concept shapes the concept of the development 
of society and its culture, certain tastes, views, needs and perceptions, that is, the culture of consumption in general. The world is experiencing a rapid development of market relations, within the framework of which there is a constant intensification and diversification of production, ensuring competitiveness becomes a priority task for all market participants. This, of course, affects the quality of the sociocultural process of our time, and consumption has acquired the status of a fundamental factor in the society functioning. Now the consumption culture is becoming more important as one of the modern cultural forms. Today it bears in itself all those ideals, values, norms, attitudes, meanings, traditions, which were both formed in the course of the development of consumer society, and influenced its formation as well.

Penetration of marketing in many spheres of life has led to a certain aesthetic worldview, a picture of the world of an individual. That is why the phenomenon of marketing aesthetics today acquires special significance. Its specificity lies in the fact that this concept influences many aspects of the life of society, thereby becoming a significant socio-cultural practice that shapes the surrounding reality. Thus, the aesthetics of marketing today is also the main tool for conducting an effective market strategy, and a factor contributing to the formation of culture of consumption and the diversification of its forms.

\section{References}

Belanche, D., Casaló, L.V. \& Guinalíu, M. (2013). The Role of Consumer Happiness in Relationship Marketing. In Journal of Relationship Marketing. 12 (2), 79-94. http://dx.doi.org/10.1080/15332667.20 13.794099 .

Brezhneva, V.M. (2012). Estetika marketinga [Aesthetics of marketing]. In Aktual'nye voprosy sovremennoi nauki. Materialy mezhdunarodnoi nauchno-prakticheskoi konferentsii [Topical issues of modern science. Materials of the International Scientific and practical conference]. Kursk, 254-258.

Carpenter, J.M., Moore, M., Alexander, N. \& Doherty, A.M. (2013). Consumer demographics, ethnocentrism, cultural values, and acculturation to the global consumer culture: A retail perspective. In Journal of Marketing Management, 29 (3-4), 271-291 http://dx.doi.org/10.1080/0267257X.2013.766629.

Charters, S. (2006). Aesthetic Products and Aesthetic Consumption: A Review. In Consumption Markets \& Culture. 9 (3), 235-255. http://dx.doi.org/10.1080/10253860600772255.

Hewer, P. \& Brownlie, D. (2010). On market forces and adjustments: acknowledging consumer creativity through the aesthetics of 'debadging'. In Journal of Marketing Management. 26 (5-6), 428440. http://dx.doi.org/10.1080/02672570903458730.

Ilyin, V. (1998). Povedenie potrebitelei [Consumer behaviour]. Moscow, Smysl, 180 p.

McCort, D.J. \& Malhotra, N.K. (2008). Culture and Consumer Behavior: Toward an Understanding of Cross-Cultural Consumer Behavior in International Marketing. In Journal of International Consumer Marketing. 6 (2), 91-127. http://dx.doi.org/10.1300/J046v06n02_07.

Petkus, E., Budeva, D., Chung, C. \& Dzhogleva, H. (2011). Marketing Outputs as Art? Bringing an Aesthetic Sensibility to the Marketing Curriculum. In Marketing Education Review. 21 (2), 113-124.

Novtorov, V.E. (2011). Kul'tura marketinga: uchebnoe posobie [Marketing culture: student's book]. Omsk, Omsk State University, 244 p. 
Riumin, S.G. (2014). Problema kons'iumerizma v sovremennoi kul'ture i eticheskoe nasledie Ivana Il'ina [The problem of consumerism in modern culture and aesthetic heritage of Ivan Ilyin]. In Kul'tura i obrazovanie [Culture and education], 12, 34-38.

Schmitt, B, Simonson, A. (1997). Marketing Aesthetics: The Strategic Managing of Brands, Identity and Images. New York: The Free Press, 368.

Stepanova, M.V. (2014). K analizu sovremennogo diskursa estetiki marketinga [To the analysis of modern discourse of marketing aesthetics]. In Aspirantskii vestnik Povolzh'ia [Volga region postgraduate newsletter], Samara, 3-4, 48-50.

Thrassou, A. \& Vrontis, D. (2009). A New Consumer Relationship Model: The Marketing Communications Application. In Journal of Promotion Management, 499-521 http://dx.doi. org/10.1080/10496490903281270.

Venkatesh, A. \& Meamber, L. A. (2008). The aesthetics of consumption and the consumer as an aesthetic subject. In Consumption Markets \& Culture, 11(1), 45-70. http://dx.doi.org/10.1080/ 10253860701799983.

Zhukova, T.N. (2013). Rol' estetiki v strategii brendinga [The role of aesthetics in the strategy of branding]. In Vestnik INZHEKONA. Seriia Ekonomika. [Newsletter of UNECON. Economy series], $6(65), 43-47$.

\title{
Эстетический концепт маркетинга \\ как фактор формирования современной \\ потребительской культуры
}

\author{
Е.А. Ноздренко \\ Сибирский федеральный университет \\ Россия, 660041, Красноярск, пр. Свободный, 79
}

Формирование потребительской культуры является одним из основополагающих способов взаимодействия с обществом и управления его сознанием. Данный факт обусловливает проникновение маркетинга во все сферы жизнедеятельности, а постоянный поиск новых способов стимулирования потребления актуализирует разработку его эстетического кониепта. В современных условиях данный феномен приобретает особую актуальность, поскольку выступает и основным инструментом эффективной рыночной стратегии, и одним из факторов, способствующих формированию культуры потребления, а значит, культуры общества в целом.

Ключевые слова: маркетинг, эстетика, реклама, культура, потребитель, эстетическая кониепџุия.

Научная специальность: 24.00.00 - культурология. 